O ano de 2020 encerrou com a sombra da pandemia do COVID-19 e o ano de 2021 inicia, infelizmente, nesta mesma situação. Porém, agora, o mundo tem mais conhecimento acerca do vírus e avançou-se na criação de uma estrutura para enfrenta-lo e para uma nova normalidade.

Os avanços, sociais e farmacêuticos, se devem a cientistas que se debruçaram e não mediram esforços para atenuar e remediar o cenário sombrio que o mundo vem atravessando. Coube a ciências sociais aplicadas debruçar-se sobre efeitos, consequências, bem como discutir formas de lidar com as marcas que ficarão. Assim, que a presente edição deve ser lida: como uma reflexão acadêmica que tangencia as questões do novo normal que iniciou sua instauração tão logo a humanidade viu-se diante do fantasma do COVID-19.

O artigo "Mínimo existencial, assistência social e estado de direito - análise de decisão proferida pelo Tribunal Constitucional Federal da Alemanha" oferece uma excelente oportunidade de analisar o direito comparado e buscar o aprimoramento das ferramentas jurídicas pátrias. Na mesma linha de instituir um debate internacional, apresenta-se o trabalho "Polygamy against moral or against law? a comparative study between brazilian law and islamic law". Neste último, o vies civilista cede espaço para uma abordagem moral muito pertinente a atualidade e ao constitucionalsimo contemporâneo, no qual as cartas constitucionais assumem o papel de emanciapação do inidívido.

O ambiente educacional, extremamente afetado pela pandemia, recebeu espaço de destaque, ao oportunizar que duas reflexes viessem a público: "A desconstrução do mito da democracia racial e o racismo estrutural no Brasil: educação e transformação social" e "A função do ensino jurídico para a formação do jurista do século XXI: um relato de experiência".

No Brasil, retomou-se o debate acerca da reforma da administração pública, e para contribuir cientificamente com ele, publica-se o trabalho "Da administração pública burocrática à gerencial: o desafio da politização da burocracia no presidencialismo de coalizão".

Para contribuir com a discussão referentes as novas tecnologias no mundo disruptivo apresentase as seguintes reflexões: "Aceleração, incubação e ecossistema empreendedor: análise jurídica das startups" e "Intellectual property rights in nanotechnology: who owns the atoms?"

Após uma rápida apresentação e contextualização da presente edição, desejo a tod@s uma excelente leitura!.

\title{
Denise Bittencourt Friedrich
}

